\title{
Comparison of Antioxidant Activity of Peel and Pulp Part of the Fruit Pyrus pyrifolia
}

\author{
POOJA UPADHYAY* and POONAM PRAKASH
}

Department of Chemistry, School of Basic Science, Sam Higginbottom Institute of Agriculture, Technology \& Sciences, (Deemed University) Allahabad- 211007, India

poojaravit2011@gmail.com

Received 16 July 2015 / Accepted 24 July 2015

\begin{abstract}
The antioxidant activity of the peel and pulp of pear was compared in this work. In DPPH (1,1-diphenyl-2-picryl hydroxyl) assay the methanol extract of peel showed $75.20 \%$ activity which was much higher than pulp extract which was $52.38 \%$. And in reducing assay peel extract showed 0.612 while the pulp extract showed 0.568 activities. Thus, the result indicated that pear peel exhibited higher antioxidant activity than pulp so it was concluded that the pear fruit has a viable source of natural antioxidants for the functional food and in medicinal application also.
\end{abstract}

Keywords: Pyrus pyrifolia, Antioxidant activity, DPPH (1, 1-diphenyl-2- picryl hydroxyl), Reducing power assay, Ascorbic acid

\section{Introduction}

Among fruits, pear is a typical fruit of temperate regions, belonging to the family Rosaceae, with delicate pleasant taste and a designer shape. Previous studies on pear fruit have focused on its chemical composition such as sugars, organic and fatty acids, minerals, amino acids, volatiles, vitamins and phenolics ${ }^{1-6}$. The overall nutritional value of fruit can be better understood by assessing their antioxidant activity ${ }^{7}$. The phenolic compounds present in the fruit mainly responsible for the antioxidant effect ${ }^{8-10}$. Though, the distribution of antioxidants may vary among different parts such as peel and pulp of the same fruit ${ }^{11-12}$. Many researchers have showed that the peel of several fruit such as citrus, apple and mango have shown higher antioxidant activity than the pulp fractions ${ }^{13}$. Even the pear skin have also much higher and more varied phenolics contents than the flesh of the fruit ${ }^{14-18}$.

\section{Experimental}

Fruits were purchased from the local market of Allahabad, India.

Preparation of extract

Peel and pulp of $1 \mathrm{~g}$ pear was chopped and shade dried at room temperature. After drying it was soaked into methanol for $48 \mathrm{~h}$. Then it was filtered and concentrated to dryness under reduced pressure. 


\section{Scavenging activity on DPPH radical}

The DPPH radical scavenging assays elucidated by Chan et al. ${ }^{19}$ was followed.

\section{Reducing power assay}

Antioxidant activity by reducing power assay method was developed by Yen and $\operatorname{Duh}^{20}$ was as followed.

\section{Results and Discussion}

The result of antioxidant activity by DPPH method showed that at $200 \mu \mathrm{g} / \mathrm{mL}$ of methanol extract of peel exhibited free radical scavenging potential was $17.31 \%$ (Table 1) which is higher than the extract of pulp (14.29\%). Likewise, in $400 \mu \mathrm{g} / \mathrm{mL}$ extract of peel showed $32.82 \%$ while pulp extract showed $25.58 \%$. Peel methanol extract of $600 \mathrm{ug} / \mathrm{mL}$ had higher free radical scavenging activity (47.36\%) than extract of pulp (37.57\%). Whereas, 800 $\mu \mathrm{g} / \mathrm{mL}$ of peel extract had $75.20 \%$ activity which is higher than the pulp extract $(52.38 \%)$. It was observed that both the extract had lower antioxidant activity compared to ascorbic acid (78.06\%) and the peel had the higher antioxidant activity than the pulp.

The result of antioxidant activity by reducing power assay as shown in Table 2 , it is evident that the peel and pulp extract of methanol showed maximum absorbance at $800 \mu \mathrm{g} / \mathrm{mL}$ 0.612 and 0.568 respectively. The most utilized solvent for determination of the radical scavenging activity by DPPH is methanol ${ }^{21}$. The data showed that both the extracts increased their reducing ability when the concentration of extracts was increased but both had lowest reducing power as compared to ascorbic acid.

Table 1. DPPH free radical scavenging activity of pulp and peel extract of pear fruit

\begin{tabular}{ccccccc}
\hline Conc., $\mu \mathrm{g} / \mathrm{mL}$ & $\%$ & Ascorbic acid & $\%$ & Pulp extract & $\%$ & Peel extract \\
\hline 200 & 68.87 & $0.061 \pm 0.0021$ & 14.29 & $0.343 \pm 0.0237$ & 17.31 & $0.597 \pm 0.0706$ \\
400 & 69.89 & $0.060 \pm 0.0015$ & 25.58 & $0.298 \pm 0.0032$ & 32.82 & $0.484 \pm 0.0558$ \\
600 & 71.42 & $0.056 \pm 0.0025$ & 37.57 & $0.290 \pm 0.0085$ & 47.36 & $0.38 \pm 0.0553$ \\
800 & 78.06 & $0.043 \pm 0.0015$ & 52.38 & $0.271 \pm 0.0100$ & 75.20 & $0.179 \pm 0.0471$ \\
\hline
\end{tabular}

Values were expressed as MEAN \pm S.D. $(n=3)$

Table 2. Reducing power activity of pulp and peel extract of pear fruit

\begin{tabular}{cccc}
\hline Conc., $\mu \mathrm{g} / \mathrm{mL}$ & Ascorbic acid & Pulp extract & Peel extract \\
\hline 200 & $0.545 \pm 0.0030$ & $0.372 \pm 0.0137$ & $0.445 \pm 0.0080$ \\
400 & $0.604 \pm 0.0074$ & $0.413 \pm 0.0025$ & $0.495 \pm 0.0127$ \\
600 & $0.634 \pm 0.0053$ & $0.499 \pm 0.003$ & $0.565 \pm 0.0145$ \\
800 & $0.695 \pm 0.0061$ & $0.568 \pm 0.0045$ & $0.612 \pm 0.0076$ \\
\hline \multicolumn{4}{c}{ Values were expressed as $M E A N \pm S . D .(n=3)$}
\end{tabular}

The highest activity in peel rather than pulp has also been showed in several fruits ${ }^{12,13}$. Many researchers have showed that the pear skin has higher activity than pulp of the fruit ${ }^{14-18}$.

\section{Conclusion}

The result of the study suggests that both, the peel as well as the pulp part of the pear fruit have showed antioxidant activity but the peel had higher antioxidant activity than pulp.

\section{References}

1. Chen J L, Wang Z F, We J H, Wang Q and Hu X S, Food Chem., 2007, 104(1), 268275; DOI:10.1016/j.foodchem.2006.11.038 
2. Colaric M, Stampar F, Solar A and Hudina M, J Sci Food Agric., 2006, 86(14), 2463 2467; DOI:10.1002/jsfa.2644

3. Ferreira D, Guyot S, Marnet N, Delgadill L, Renard C M and Coimbra M A, J Agric Food Chem., 2002, 50(16), 4537-4544; DOI:10.1021/jf020251m

4. Galvis-Sanchez A C, Gil-lzquierdo A and Gil M I, J Sci Food Agric., 2003, 83(10), 995-1003; DOI:10.1002/jsfa.1436

5. Ramadan M F and Morsel J T, Food Chem., 2003, 83(3), 447-456; DOI:10.1016/S0308-8146(03)00128-6

6. Wang J, Xu J Z, Chen H J and Li S L, Food Technol., 2002, 9, 71-73.

7. Scalzo J, Politi A, Pellegrini N, Mezzetti B and Battino M, Nutrition, 2005, 21(2), 207-213.

8. Amiot M J,Tacchini M and Auber S Y, J Agric Food Chem., 1995, 43(5), 1132-1137; DOI:10.1021/jf00053a004

9. Leontowicz M, Gorinstein S, Leontowicz H, Krzaeminski R, Lojek A, Katrich E, Ciz M, Martin- Belloso O, Soliva-Fortuny R, Haruenkit R and Trakhtenberg S, J Agric Food Chem., 2003, 51(19), 5780-5785; DOI:10.1021/jf030137j

10. Salta J, Martins A, Santos R S, Neng N R, Nogueira J M F, Justino J and Rauter A P, J Funct Foods., 2010, 2(2), 153-157; DOI:10.1016/j.jff.2010.02.002

11. Soong Y and Barlow P, Food Chem., 2004, 88(3), 411-417; DOI:10.1016/j.foodchem.2004.02.003

12. Manzoor M, Anwar F, Mahmood Z, Rashid U and Ashraf M, Molecules, 2012, 17(6), 6491-6506; DOI:10.3390/molecules 17066491

13. Jayaprakasha G, Singh R and Sakariah K, Food Chem., 2001, 73(3), 285-290; DOI:10.1016/S0308-8146(00)00298-3

14. Escarpa A and Gonzalez C, Crit Rev Anal Chem., 2001, 31(2), 57-139; DOI:10.1080/20014091076695

15. Imeh U and Khokhar S, J Agric Food Chem., 2002, 50(22), 6301-6306; DOI:10.1021/jf020342j

16. Oleszek W, Amiot M J and Aubert S Y, J Agric Food Chem., 1994, 42(6), 12611265; DOI:10.1021/jf00042a002

17. Schieber A, Keller P and Carle R, J Chromatogr A, 2001, 910(2), 265-273; DOI:10.1016/S0021-9673(00)01217-6

18. Es-Safi N E, Guyot S and Ducrot P H, J Agric Food Chem., 2005, 54(19), 6969-6977; DOI:10.1021/jf061090f

19. Chan E W C, Lim Y Y and Omar M, J Food Chem., 2007, 104(4), 1586-1593; DOI:10.1016/j.foodchem.2007.03.023

20. Yen G C and Duh P D, J Am Oil Chem Soc., 1993, 70(4), 383-386; DOI:10.1007/BF02552711

21. Gupta M, Mazumder U and Gomathi P, Asian J Plant Sci., 2007, 6(3), 533-537. 